\title{
Geospatial subsidence hazard modelling at Sterkfontein Caves
}

\author{
Hamid Ashraf ${ }^{1}$, Frederick Cawood ${ }^{2}$ \\ ${ }^{1}$ School of Mining Engineering, University of the Witwatersrand, Johannesburg, South Africa, \\ 804540@students.wits.ac.za \\ ${ }^{2}$ Professor of Mine Surveying and Coordinator: Wits Digital Mining Project, \\ School of Mining Engineering, University of the Witwatersrand, Johannesburg, South Africa
}

DOI: http://dx.doi.org/10.4314/sajg.v4i3.8

\begin{abstract}
This paper covers a GIS approach to identifying hazardous areas at the Sterkfontein Caves. It makes a contribution to risk assessment of land with shallow caves underneath it. The aim of the study is to ensure public safety in a concentrated area frequently visited by the public and is part of a programme to identify appropriate digital technologies for mining. The geo-hazard subsidence model includes historic subsidence occurrances, terrain (water flow) and water accumulation. Water accumulating on the surface will percolate and reduce the strength of the soil mass, possibly inducing subsidence. Areas for further geotechnical investigation are identified, demonstrating that a GIS, geospatial reclassification tool has great potential for strengthening current risk assessment approaches in mining.
\end{abstract}

\section{Introduction}

Land subsidence is a result of either gradual or sudden movement of the Earth's surface due to subsurface movement of the rock or strata. It also refers to the vertical downward movement of a mass (soil or rock) due to loss of underground strength (Pacheco, et al., 2006). There are many causes of subsidence which include water ingress, imbalance discharge due to water mining of an aquifer system; drainage of organic soil; underground mining (especially coal mining); consolidation of sedimentary deposits according to geological time scales; subsidence due to tectonic movements; localized collapse of subsurface cavities due to volume change or loss of underground support and the collapse of the roof of an underground cave system. The collapse of land over natural underground voids can be a frequent phenomenon in underground cave systems. Sinkholes can appear on ground where the roof of an underground cave collapses. The collapse of cave roofs can be due to rock movement, loss of strength of underground soil, and dissolution of minerals with underground water (Klimchouk, 2009). However, the most common factor for erosion and voids' formation in caves is limestone erosion. Subsidence can be of three types: funnel-shaped,bowl-shape, and circular shaped. In addition, the extent of land subsidence can vary from $1 \mathrm{~m}$ to as much as $30 \mathrm{~m}$.

Sterkfontein Caves are located in the Cradle of Humankind which has significant archaeological value. It is undergoing a variety of rheological distresses. There is a need to study the natural occurring surface deformations which can result in the subsidence of land. The caves are frequently visited by the public, making risk assessment and hazard monitoring a requirement to ensure the safety of visitors.

Land-subsidence hazard is common in limestone cave formations such as at Sterkfontein caves. This type of subsidence is associated with subcircular surface depression or structure collapse when small underground voids collapse(R. Brinkmann, et al. 2008).

Land subsidence is broadly divided into two categories: human activity induced subsidence and geologically induced subsidence. Human-induced subsidence has been extensively investigated. Particularly, it has been found that extensive groundwater withdrawal can result in substantial subsidence and loss of property (Abidin, et al., 2001). Gao and Alexander did subsidence hazard modelling and included rock geology and distance to the nearest sinkhole, but did not include topographical land use factors into their model (Gao and Alexander, 2008). Green, et al. (2002) studied Karst mapping using GIS and described hydrology as one of the factors of subsidence and sinkhole formation. They also included bedrock, fractures and faults, and soil depth as major contributing factors.

Rawashdeh,et al. (2012) developed a sinkhole probability map based on factors such as sinkhole distribution, bedrock geology and depth to bedrock based on the nearest neighbour analysis in a GIS system. Gao and Alexander(2001) suggested that subsidence areas can have increasing clusters because of similar geological and topographic conditions.

Gao (2002) also designed and developed a GIS-based database for spatial analysis of Karst features and contributing factors. Pirasteh and Rizvi (2011) studied the location and mapping of sinkholes on an aerial photograph using remote sensing techniques.

\footnotetext{
${ }^{1}$ Geographic information system.
} 
Hobbs (2011) studied the surface and ground water resources in the Cradle of Humankind. He also discussed the effects of surface and ground water on the Karst system of Sterkfontein caves. Oosthuizen and Richardson (2011) studied the mechanism of sinkhole formation in South Africa in areas underlain by dolomite rock. Durand and Peinke (2010) studied the Karst ecology of the Sterkfontein caves in South Africa.

\section{Study Area}

The Sterkfontein caves are located about $50 \mathrm{~km}$ north-west of Johannesburg within the Cradle of Humankind World Heritage Site. It is situated in the Gauteng province of South Africa and the site straddles the boundary between the Oaktree and Monte Christo formations. The strata dip about $30^{\circ}$ to the NW. The passages follow two main directions of sub-vertical joints; the dominant one is mostly $\mathrm{W}$ to $\mathrm{WNW}$ and the subordinate one varies from $\mathrm{N}$ to NNE. The cave system is restricted to a volume of about $200 \mathrm{~m}$ x $250 \mathrm{~m}$ x $50 \mathrm{~m}$ (Martini, et al., 2003). Sterkfontein Caves consist of a labyrinth network of passages which are controlled by joints or broad flat chambers - the result of dissolution of chertfree beds sandwiched between cherty dolostone. The study area is shown in Figure 1.

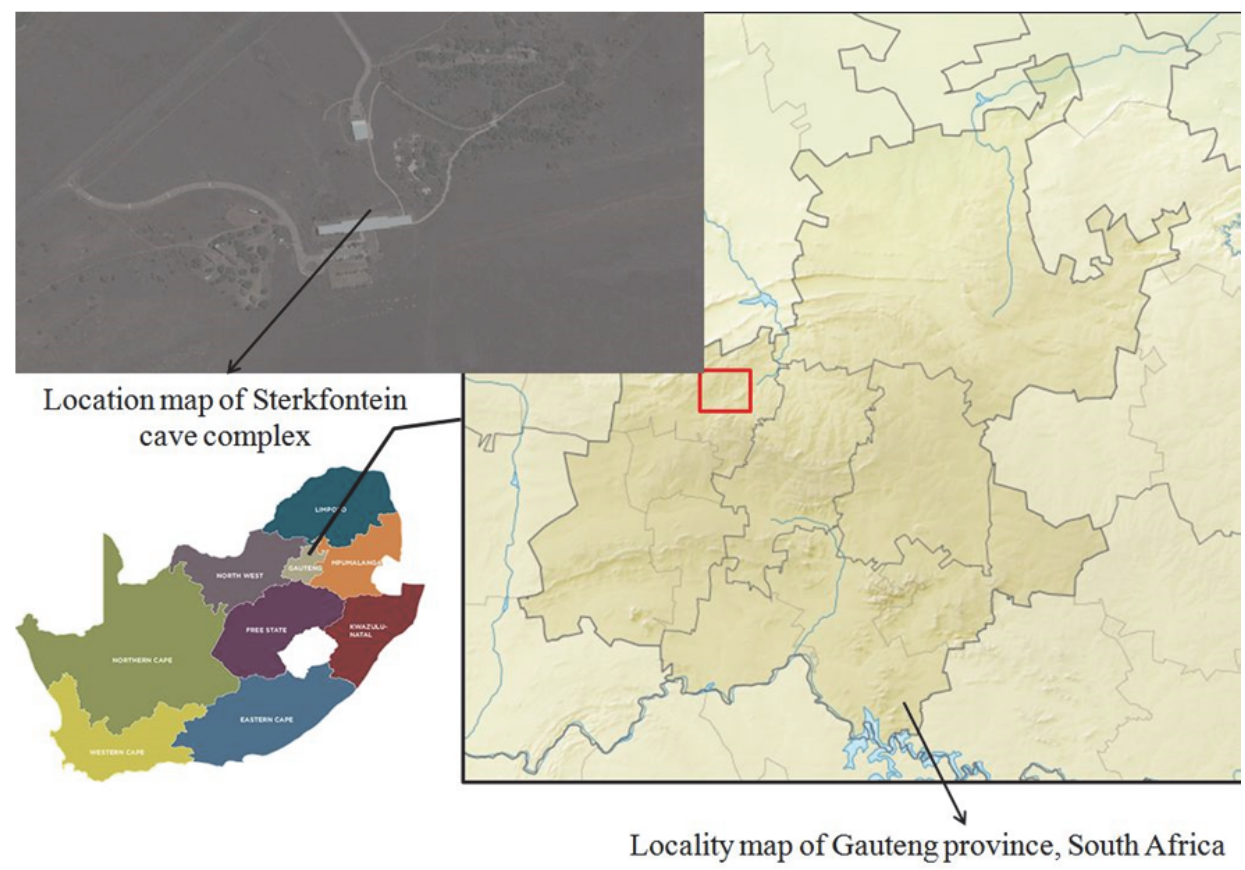

Figure 1. Location map of the study area

\section{Methodology}

\subsection{Data and analysis concept}

The data used in this study comprised remotely sensed imageries and related tabulated data. The $10 \mathrm{~m}$ spatial resolution ${ }^{2}$ SPOT 5 imagery was acquired from South African National Space Agency (SANSA). The imagery was generated on 10 April 2014 with a radiometric resolution of 8 bit $^{3}$. The second imagery is a $2.5 \mathrm{~m}$ resolution (resampled) aerial photograph produced by Geo Terra Image (GTI) in 2012 (Table 1). The spatial data were georeferenced to conform to WGS $84^{4}$ projection and then converted to GIS format for multi-criteria analysis.

\footnotetext{
${ }^{2}$ Resolution means smallest observable (measurable) difference in a digital image.

${ }^{3}$ Radiometric resolution is the ability of an image to record many levels of brightness. The finer the radiometric resolution of the sensor, the more sensitive it is in detecting small differences or omitted energy. Image data is represented by positive digital numbers which vary from 0 to a selected power of 2 . This range corresponds to the number of bits used for coding numbersin binary format. Each bit records an exponent of power 2 . Thus, if 8 bits are used to record the data, there would be $2^{8}=256$ digital values available, ranging from 0 to 255 .

${ }^{4}$ World Geodetic System 1984.
} 
South African Journal of Geomatics, Vol. 4, No. 3, August 2015

Table 1. Spatial data selected for the model

\begin{tabular}{|c|c|c|c|c|}
\hline S/No & Data set & Data type & Scale & Extracted data \\
\hline 1 & $10 \mathrm{~m}$ SPOT 5 imagery & Raster & $10 \mathrm{~m}$ resolution & Sinkholes \\
\hline 2 & $2.5 \mathrm{~m}$ aerial photograph & Raster & $2.5 \mathrm{~m}$ resolution & Land cover \\
\hline 3 & Global digital elevation model & Raster & $30 \mathrm{~m}$ resolution & Slope \& Water accumulation \\
\hline 4 & Digital elevation model & Raster & $20 \mathrm{~m}$ resolution & Slope \& Water accumulation \\
\hline
\end{tabular}

\subsection{Data pre-processing}

Prior to the use of SPOT 5 and aerial photographs, both were enhanced and then geometrically corrected. Some visual screen digitization was also done for features like roads and small water paths. As the area under investigation is only confined to the boundary of Sterkfontein caves and its surroundings, it was necessary to extract the area of interest from the complete digital data. This extraction reduced the calculations required to be done by the GIS model and also saved time. Prior to extraction, a new shape file with the extent shown in Figure 2 was created in ArcGIS environment. The shape file is in the polygon vector format and is in WGS 84 coordinate system.

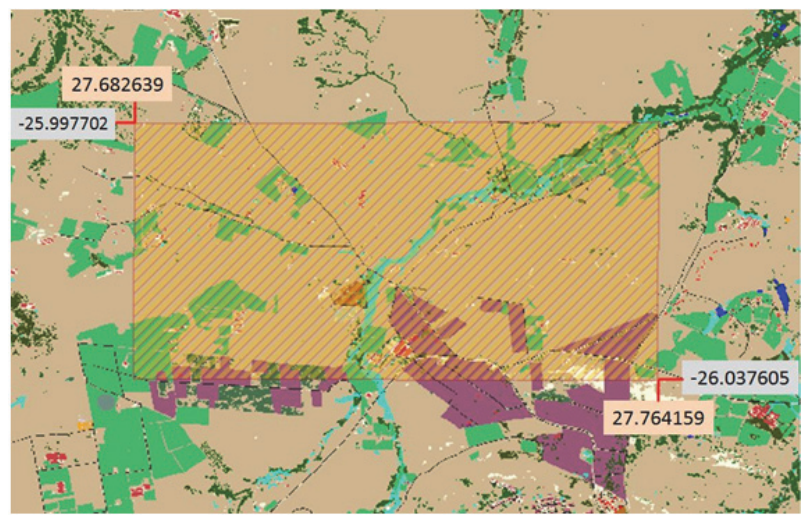

Figure 2. Extents of shape file for extraction of required data

\subsection{Image enhancement}

Image enhancement was done by traversing low pass $3 \times 3$ cell neighborhood window filters ${ }^{5}$ over the raster image. A low-pass filter smooths the data by reducing local variation and removing noise. It calculates the average value for each $3 \times 3$ neighborhood. The effect is that the high and low values within each neighbourhood would average out, reducing the extreme values in the data. The image enhancement technique helps to produce better-represented scene for clear visual presentation and also helps clear information contents for the interpreter.

\subsection{Digital elevation model (DEM)}

The DEM used for the spatial analysis was the $30 \mathrm{~m}$ global digital elevation model. $20 \mathrm{~m}$ spatial resolution DEM produced by Geo Terra Image (GTI) was also used for calculating the slopes.

\subsection{Geospatial subsidence modelling design}

The first step in the modelling was to create a conceptual model. The factors responsible for land subsidence were carefully selected so that they corresponded to the area of interest. The conceptual model is given in Figure 3.

${ }^{5}$ The Filter tool in ArcGIS was used to eliminate spurious data or enhance features otherwise not visibly apparent in the data. Filters create output values by a moving, overlapping 3 x 3 cell neighborhood window that scans through the input raster. As the filter passed over each input cell, the value of that cell and its 8 immediate neighbours were used to calculate the output value. 


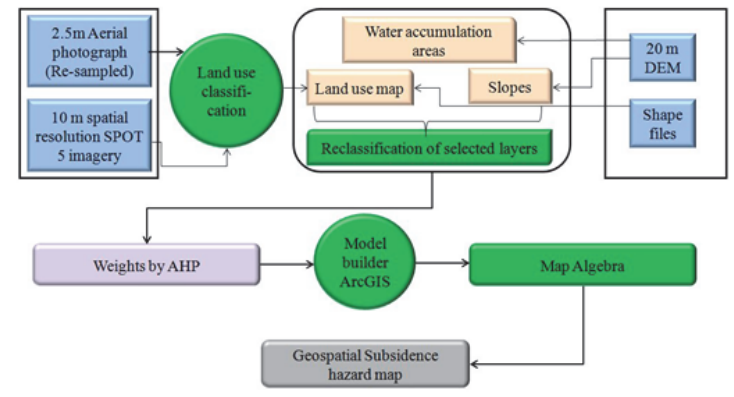

Figure 3. Conceptual model for the geospatial subsidence hazard map of the Sterkfontein cave area

The preparation of subsidence maps for the Sterkfontein caves involved digital data input. Three types of data were used. The land cover map was extracted from the $2.5 \mathrm{~m}$ aerial photograph which was further classified into fifteen landuse classes. The land-use classifications are given in Table 2.

Table 2. Land-Cover Legend: 2012 Release GTI Gauteng Land-Cover Dataset

\begin{tabular}{|c|c|c|c|}
\hline S/No & Class name & Subclass & Description \\
\hline \multirow{4}{*}{1} & \multirow{4}{*}{ Buildings } & General & Permanent structures varying in height. \\
\hline & & Schools & Permanent structures associated with educational facilities. \\
\hline & & Campuses & $\begin{array}{l}\text { Permanent structures associated with education campuses and associated } \\
\text { infrastructure. }\end{array}$ \\
\hline & & Sport stadiums & Large structures comprising both central sports field and surrounding stands. \\
\hline 2 & \multicolumn{2}{|c|}{ School grounds } & Open areas within the school boundary. \\
\hline 3 & \multicolumn{2}{|c|}{ Sports \& recreation } & Areas and structures used for sport and recreational activities. \\
\hline 4 & \multicolumn{2}{|l|}{ Industrial } & Large buildings and structures associated with industrial activities. \\
\hline 5 & Residential & Township & Permanent and semi-permanent structures. \\
\hline 6 & Residential & Small holdings & Areas of low residential concentrations on the outskirts of towns and cities. \\
\hline 7 & Residential & Village & Low density residential areas. \\
\hline 8 & \multicolumn{2}{|l|}{ Roads } & National, regional, and major roads. \\
\hline 9 & \multicolumn{2}{|l|}{ Rail } & Main surface rail networks. \\
\hline \multirow{4}{*}{10} & \multirow{4}{*}{ Vegetation } & Bush-clumps & Bush- and shrub-dominated areas in a natural land. \\
\hline & & Forest & Tree-dominated areas including forests, woodland, and very tall bush areas. \\
\hline & & Tree (Planted) & Tree-dominated areas in the form of planted forest plantations. \\
\hline & & Grassland & Planted and natural grass-dominated areas. \\
\hline 11 & \multicolumn{2}{|c|}{ Cultivated land } & Cultivated land of any type (Commercial/private) \\
\hline 12 & \multicolumn{2}{|l|}{ Mines } & $\begin{array}{l}\text { Combination of extraction pits, waste and storage dumps associated with } \\
\text { mining. }\end{array}$ \\
\hline 13 & \multicolumn{2}{|l|}{ Open } & Open areas with little or no vegetation cover. \\
\hline 14 & \multicolumn{2}{|l|}{ Water } & Water whether natural or man-made, flowing or static. \\
\hline 15 & \multicolumn{2}{|c|}{ Bare rock and soil } & Naturally occurring, non-vegetated rock, sand and soil. \\
\hline
\end{tabular}

Source: Updated Gauteng 2012 release Land-Cover classes by Geo terra image 
The existing subsidence areas were obtained from the $10 \mathrm{~m}$ spatial resolution SPOT 5 imagery. A shape file was created in WGS 84 coordinate system to mark the present subsidence areas as points. These points were also confirmed through ground observations. The points are shown in Figure 4.

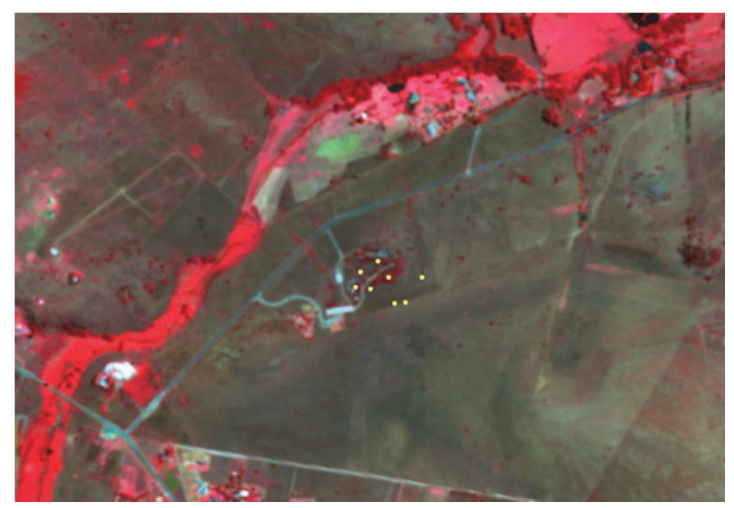

Figure 4. Yellow dots showing the already present sinkholes in the Sterkfontein cave area

Water accumulation areas and slopes were calculated from the $\mathrm{DEM}^{6}$. The spatial analyst slope tool was used to extract the slopes. The water accumulation areas were calculated by the Flow accumulation hydrological tool in ArcGIS 10.3. The direction and length of flowing body were calculated in ArcGIS and included as an input shape file. Similarly, the contour map was included as a separate shape file in the input digital data.

Spatial analyst toolbox and model builder (ArcGIS applications) provides powerful tools for comprehensive, raster-based spatial modelling and analysis (Chen and Blong, 2003). In the analysis Kriging interpolation technique, Reclassification and Map algebra/ Raster calculator (ArcGIS application tools) were used to analyse the data.

Kriging interpolation technique is a statistical interpolation technique. Kriging function assumes that the distance or direction between sample points reflects a spatial correlation that can be used to explain variation in the surface (Gambolati \& Teatini, 2002). In this study, kriging Interpolation (ArcGIS application tool) was used to create the raster surface from the already present subsidence areas in the Sterkfontein cave area. However, in the model, the subsidence areas were manually added by extracting the affected cells from SPOT 5 imagery and DEM. A reclassification tool was used to assign weights to different input data in the model.

\subsection{Weighting of digital data layers}

All the factors involved in the model cannot have an equal weighting because each factor has its own importance on the outcome of subsidence hazard map. For weighting a multi-criteria decision analysis approach was adopted, which involved criteria of varying importance. Criterion-weighting expresses the relative importance by assigning a weight to each criterion. There are several approaches to criteria weighting. However, Analytical Hierarchical Process (AHP) is one of the most extensively used in the GIS spatial analysis(Aceves-Quesadaet al. 2007). The AHP is a multi-criteria mathematical evaluation method using a pairwise comparison method. Developed by Saatay in 1980, this method involves pairwise comparisons to create a ratio matrix. It takes pairwise comparisons as input and produces the relative weights as output. A pairwise comparison of factors was carried out to assign weights to these factors in the map algebra tool in a model builder environment in ArcGIS. The pairwise comparison and the AHP process details are given in Tables 3 and 4.

Table 3. Pairwise comparison of factors considered in subsidence modelling

\begin{tabular}{|l|c|c|c|c|c|c|}
\hline \multicolumn{1}{|c|}{$\begin{array}{c}\text { Pairwise comparison } \\
\text { matrix }\end{array}$} & Water accumulation & Slope & Land use & Sinkholes & \multicolumn{2}{|c|}{ AHP } \\
\hline Water accumulation & 1 & 2 & 3 & 4 & 0.480 & $48.0 \%$ \\
\hline Slope & $1 / 2$ & 1 & 2 & 3 & 0.262 & 26.2 \\
\hline Land use & $1 / 3$ & $1 / 2$ & 1 & 2 & 0.155 & $15.5 \%$ \\
\hline Sinkholes & $1 / 4$ & $1 / 3$ & $1 / 2$ & 1 & 0.103 & $10.3 \%$ \\
\hline \multicolumn{1}{|c|}{ Total column } & 2.0833 & 4.8333 & 6.5000 & 10.05000 & Consistency ratio=2\% \\
\hline
\end{tabular}

\footnotetext{
${ }^{6}$ Digital elevation model.
} 
South African Journal of Geomatics, Vol. 4, No. 3, August 2015

Table 4. Pairwise comparison intensity of importance factors and their relative importance

\begin{tabular}{|c|l|l|l|}
\hline $\begin{array}{c}\text { Intensity of } \\
\text { importance }\end{array}$ & \multicolumn{1}{|c|}{ Definition } & $\begin{array}{c}\text { Subsidence factor and } \\
\text { their relative importance }\end{array}$ & \multicolumn{1}{c|}{ Description } \\
\hline 1 & Equal to moderate & Sinkholes & $\begin{array}{l}\text { The soil mass of a sinkholeat a particular angle of } \\
\text { repose } 7 \text { increases in radius with an increase in } \\
\text { sinkhole depth which can thus affect surrounding } \\
\text { areas. }\end{array}$ \\
\hline 2 & Moderate importance & Land use & $\begin{array}{l}\text { Bare land mass has low angle of repose }\left(30^{\circ}\right) \text { as } \\
\text { compared to grassy land or forest land }{ }^{8}\left(45^{\circ}\right) .(\text { Scott } \\
\text { et al, 1998 and US Forest Service, 2009) }\end{array}$ \\
\hline 3 & Moderate to strong & Slope & Sloping ground is prone to strength failure. \\
\hline 4 & Strong & Water accumulation & $\begin{array}{l}\text { Water accumulating in a cell will percolate and } \\
\text { subsequently reduce the strength of the soil mass }\end{array}$ \\
\hline
\end{tabular}

Source: Analytical hierarchical process, AHP

Geospatial data and geospatial analysis can be done either in raster or vector format. We selected a raster model because raster models are easy to manipulate and easy to interpret as data is in cellular format. Before we could proceed with the AHP multi-criteria analysis, we required the classification of the individual factor maps. For example, in the slope factor map, all slope angles cannot be equally weighted. Therefore, only slopes between certain angle limits were included. To understand the critical slope for subsidence triggering, we considered a mass of soil lying on a sloping ground (Figure 5). Three forces act on this mass of soil:-

- Shear stress (gs) is the force causing movement parallel to a slope which increases with slope angle.

- Shear strength (gp) is the force of internal resistance to movement or force of cohesion and friction.

- Gravitational force $(\mathrm{G})$ is the force with which body of the mass is attracted towards the centre of the earth.

Now, if a $1 \mathrm{lb}$. mass is lying on ground sloping at $30^{\circ}$ (Figure 5), the shear and strength component of this force can be calculated by solving the two force triangles shown right and left of the $1 \mathrm{lb}$. gravity pull. The gs factor in the right figure is $0.87 \mathrm{lb}$ which means that the soil mass is unstable at $60^{\circ}$. Slopes between $45^{\circ}$ to $60^{\circ}$ are considered as critical and were classified in reclassification tool to get a slope factor map of the area.
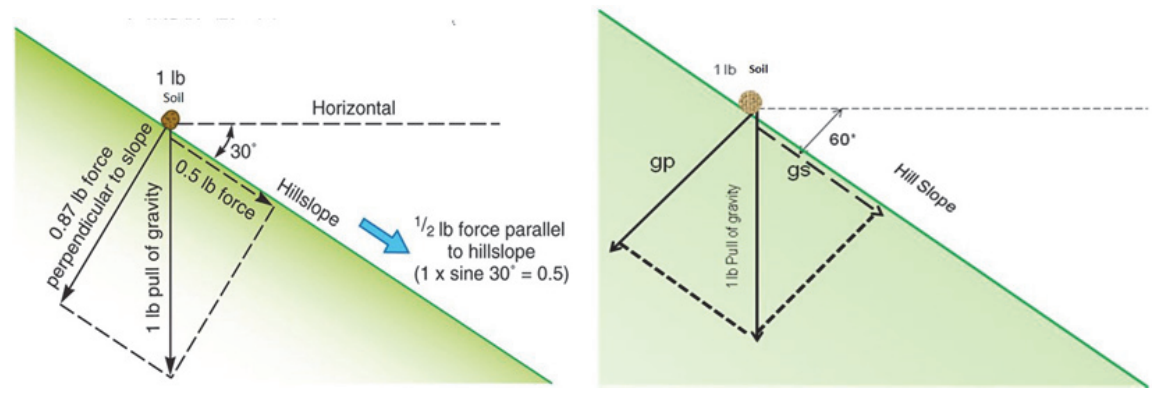

Figure 5. Soil mass of $1 \mathrm{lbs}$ lying on a slope of $30^{\circ}$ and $60^{\circ}$

Similarly, the reclassification tool in ArcGIS was used to perform the individual classification of each factor maps before assigning the AHP weights.

${ }^{7}$ The angle of repose of a soil is the gradient of the slope at which the soil settles naturally. A firm soil will have a steeper angle of repose than a loose soil. The angle of repose can be used to estimate the maximum radius of a sinkhole of a certain depth. As the opening of a sinkhole becomes larger and/or deeper, the subsequent radius will become larger. ${ }^{8}$ Vegetable earth, dry and consolidated, has a $45^{\circ}$ angle of repose as against $30^{\circ}$ for bare dry land (US Forest Service, 2009). 
The calculation unit of the subsidence Geo-hazard model is the cell ${ }^{9}(C)$, where the cell presents a metric square (Figure 6). Each contributed factor map $(F m)$ is expressed in a matrix of cells that represent the raster model of that factor. Depending on the number of factor maps $(n)$, the total contributed factors in the subsidence geo-hazard model are $\sum F m n$; for each cell of the subsidence geohazard map.

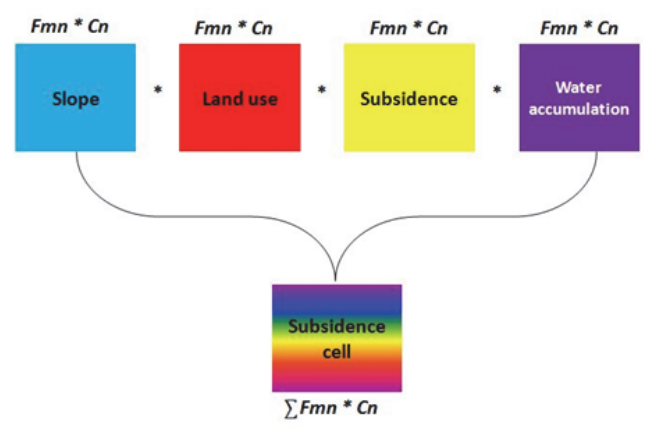

Figure 6. Cell weight influence diagram

However, the contributed factor maps have different influences. Thus, each factor map Fmn has a coefficient $C n$ that determines the influence level on the subsidence geo-hazard map. Now the total contributed factors with their influence coefficients for each cell are expressed as follows:

$$
C=\sum F m n * C n
$$

Where $C=$ value of cell in the model output;

$$
\begin{aligned}
& F m n=\text { value of that cell of the hazard factor map } m n \\
& C n=\text { influence level coefficient (AHP weight) associated with Fmn. }
\end{aligned}
$$

Each element in equation 2 was assigned a weight through AHP, and the map algebra tool calculated the final output of the model. Each output cell was the product of all the weighted factors and represented whether Fmn factor was added or not in the final output.

Model builder in ArcGIS was used to build the model that could house the map algebra tool and produce a spatial interpretation of the output map (Figure 7). The formula used in the map algebra tool was as follows:-

$$
W a * 0.480+S L * 0.262+L u * 0.155+S b * 0.103
$$

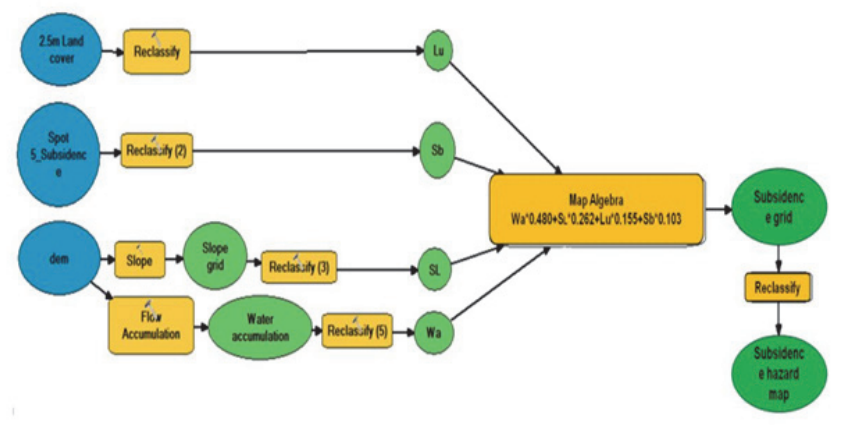

Figure 7. Subsidence hazard model in ArcGIS model builder

\section{Results and Discussion}

${ }^{9}$ Cell is defined as a picture element which has both spatial and spectral properties. The spatial property defines the dimensions of the corresponding ground area and the spectral property defines the intensity of the spectral response for a cell/ pixel in a particular band. In the context of the research, one cell on the digital elevation model represents $30 \mathrm{~m}$ on the ground and one cell on the Spot 5 imagery represents $10 \mathrm{~m}$ on the ground. 
In order to calculate the areas which are hazardeous for subsidence, we need to define the working units for calculations. A "cell" was kept as the calculation unit whose dimensions are shown in Figure 8. Each cell has x,y coordinates and a height component, to be located in geographic space. The most important factor in the geohazard subsidence model is the spatial distribution of water accumulation areas. Water accumulating in a cell will percolate and reduce the strength of the soil mass, possibly inducing subsidence. Slopes, land-use type and close proximity to the already present sinkholes are factors that directly affect the geo-subsidence model results.

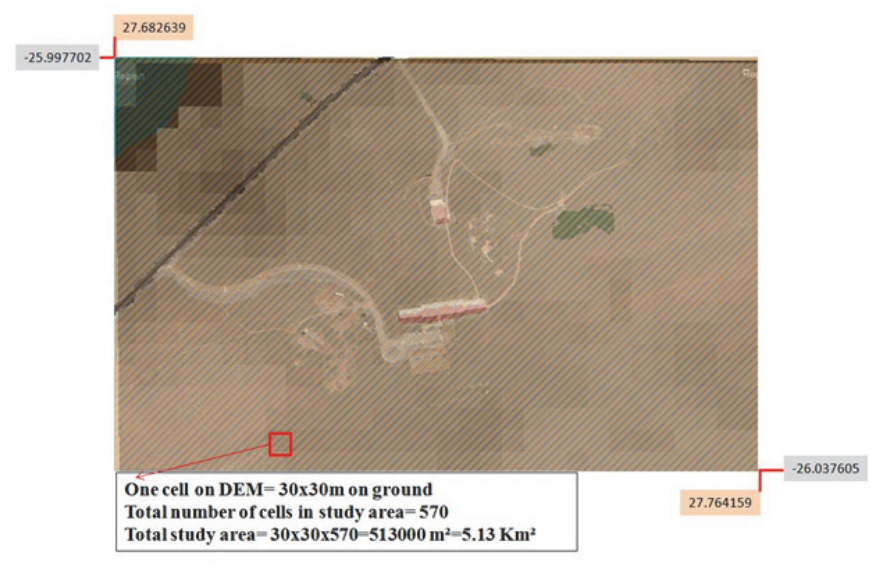

Figure 8: Extents of study area and the dimensions of the working unit "cell"

\subsection{Water accumulation hazard areas}

Cells with a high-flow accumulation are areas of concentrated flow. Cells with a flow accumulation of 0 are local topographic highs (for example, ridges). High-flow accumulating cells are concentrated in the northeast and northwest boundaries of the cave. A total of 111 cells were identified which could accumulate water in case of rainfall. This total was approximately $20 \%$ of the total ${ }^{10}$ cells in the area of interest (Table 5). Rain falling anywhere in the DEM had be able to follow a downhill path all the way to the edge of the DEM. In the first step, the flow direction was calculated. There are many different ways to distribute the flow from a cell. Here we opted for a D8 algorithm, used by spatial analyst. In D8 algorithm, there are eight valid output directions relating to the eight adjacent cells into which flow could travel (Figure 9). At each cell, a number was assigned based on the direction of the lowest elevation neighbour (steepest descent), as shown in Figure 9, so that if the elevation was lowest to the left, the output flow direction would be 16. The direction of flow is determined by the direction of steepest descent, or maximum drop, from each cell. This drop was calculated as follows:

$$
\text { minimum }_{\text {drop }}=\text { change_in_z_value/distance } * 100
$$
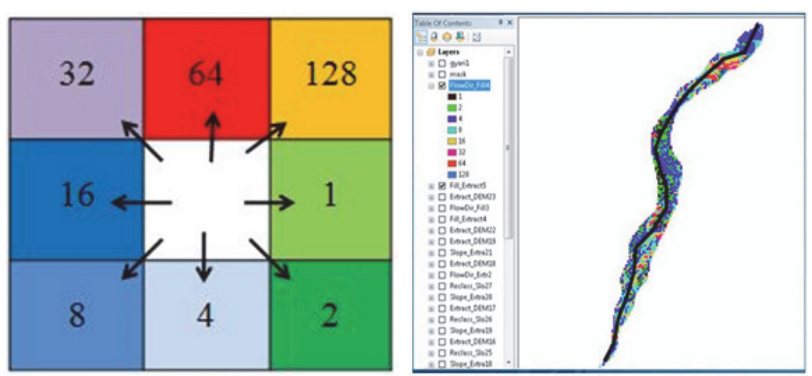

Figure 9. D8 algorithm for calculating the flow direction. Source: ArcGIS software support.

\footnotetext{
${ }^{10}$ Total cells in the study area were 570 as explained in Figure 8.
} 
The flow direction and water accumulation for each cell can be calculated by the flow accumulation tool in ArcGIS (Figure 10). The flow accumulation tool tells us how many cells are 'upstream' of a given cell. The output corresponds to the upstream drainage area of each cell. This command is recursive and can take a long time to run for large grids. We specified the output type as INTEGER ${ }^{11}$ in order to save space, as the flow accumulation was simply counting cells.

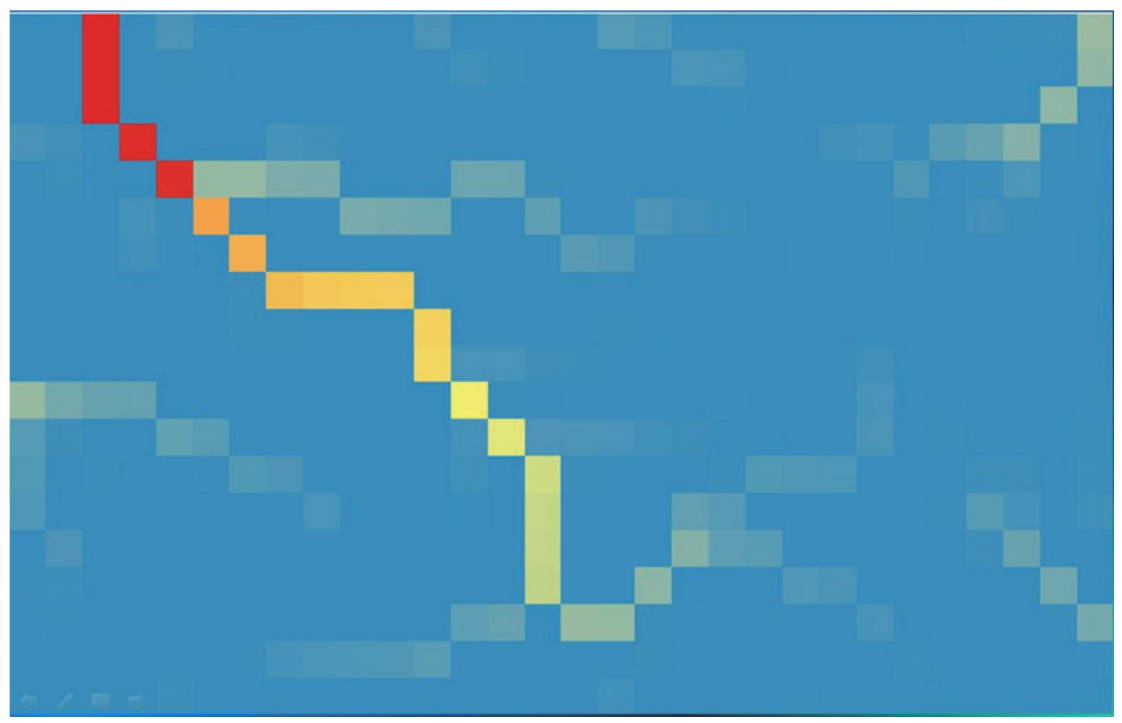

Figure 10. Water accumulation grid of the Sterkfontein caves

\subsection{Slopes hazard potential areas}

The slopes of the study area were calculated in ArcGIS using slope tool in geo-processing (Figure 10). The analysis of the slope grid revealed that most the cave areas have slopes in the range of $20-40^{\circ}$. However, there were substantial slopes in the range of 45 to $60^{\circ}$ which were critical for land subsidence.Slopes were then reclassified assigning a value of 1 to slopes between 45 to $60^{\circ}$ and 0 values to all other slopes. The reclassified slope map had 140 cells between the ranges of 45 to $60^{\circ}$. This represented approximately $24 \%$ of the total cells in the area (Table 5). The area within the red mark in Figure 11 has a high probability to sink because of their slope angle and high flow accumulation rate.

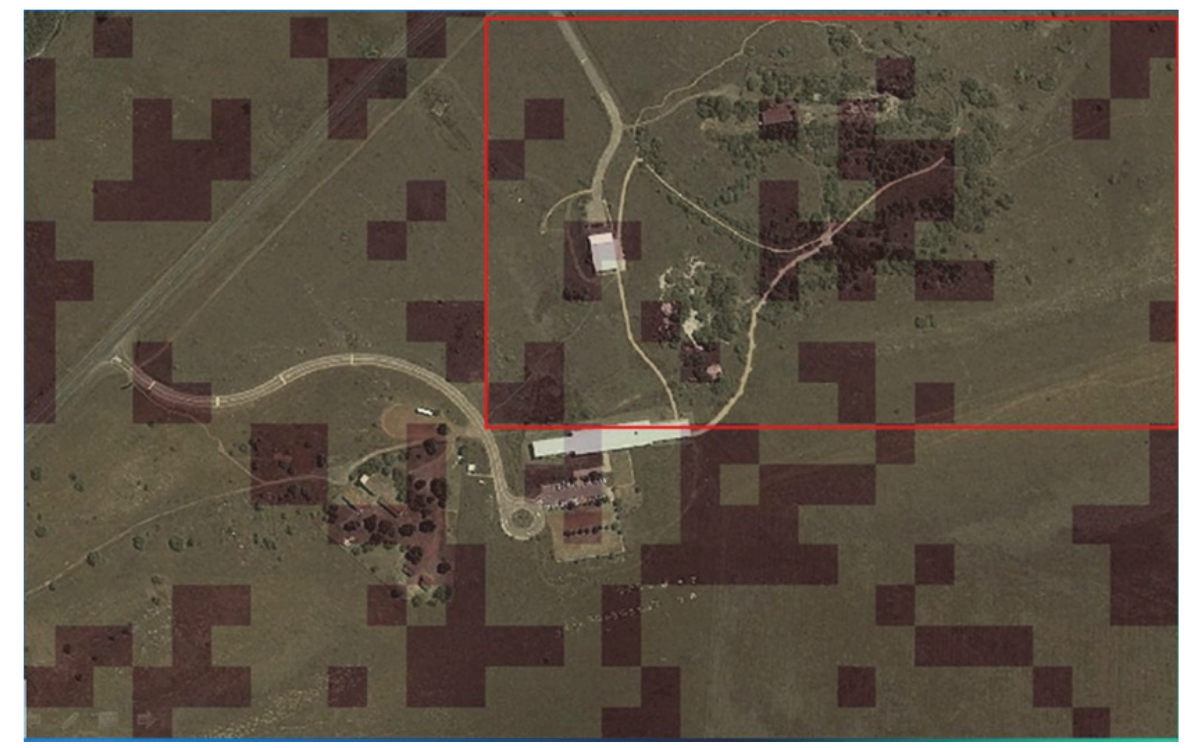

Figure 11. Slope grid of the Sterkfontein caves

\footnotetext{
${ }^{11}$ Integer is a data type to store a feature into the database. Integer raster data stores whole numbers as the values of each cell as against floating point raster data, which stores numbers with a decimal portion as the values of each cell. To reduce model calculations we used integer values in the flow accumulation tool in ArcGIS software.
} 
South African Journal of Geomatics, Vol. 4, No. 3, August 2015

Table 5.Weighting of factor maps for reclassification

\begin{tabular}{|c|c|c|c|c|c|}
\hline S/No & Factor & Value & Classification weight & Number of cells & Percent \\
\hline \multirow{3}{*}{1} & \multirow{3}{*}{ Slopes } & $\leq 45^{\circ}$ & 0 & 50 & $8.8 \%$ \\
\hline & & $45^{\circ}-60^{\circ}$ & 1 & 140 & $24.5 \%$ \\
\hline & & $\geq 60^{\circ}$ & 0 & 380 & $66.7 \%$ \\
\hline \multirow{4}{*}{2} & \multirow{4}{*}{ Land use } & Forest and trees & 0 & 13 & $2.3 \%$ \\
\hline & & Building & 1 & 7 & $1.2 \%$ \\
\hline & & Open/ bare land & 1 & 67 & $11.8 \%$ \\
\hline & & Grassland & 0 & 483 & $84.7 \%$ \\
\hline \multirow{2}{*}{3} & \multirow{2}{*}{$\begin{array}{l}\text { Proximity to } \\
\text { sinkholes }\end{array}$} & $\leq 60 \mathrm{~m}$ & 1 & 136 & $23.9 \%$ \\
\hline & & $\geq 60 \mathrm{~m}$ & 0 & 434 & $76.1 \%$ \\
\hline 4 & Water accumulation & - & 1 & 111 & $19.5 \%$ \\
\hline
\end{tabular}

\subsection{Proximity to existing sinkholes}

The angle of repose is used to estimate the maximum radius of a sinkhole of a certain depth. As a sinkhole becomes deeper, the subsequent radius will become larger to affect other areas (Pulis, 2011). There are eight sinkholes in the area, with diameters varying from $1.3 \mathrm{~m}$ to $6.1 \mathrm{~m}$. A $5 \times 5$ cell neighborhood window filter ${ }^{12}$ was used to calculate the cells affected by the sinkholes. Keeping the sink hole at centre $5 \times 5$ filter captured cells within $60 \mathrm{~m}$ of diameter. There were 136 affected cells in the area due to existing sink holes. This number is approximately $24 \%$ of total cells (Table 5). This $24 \%$ is potentially hazardous and can contribute to land subsidence.

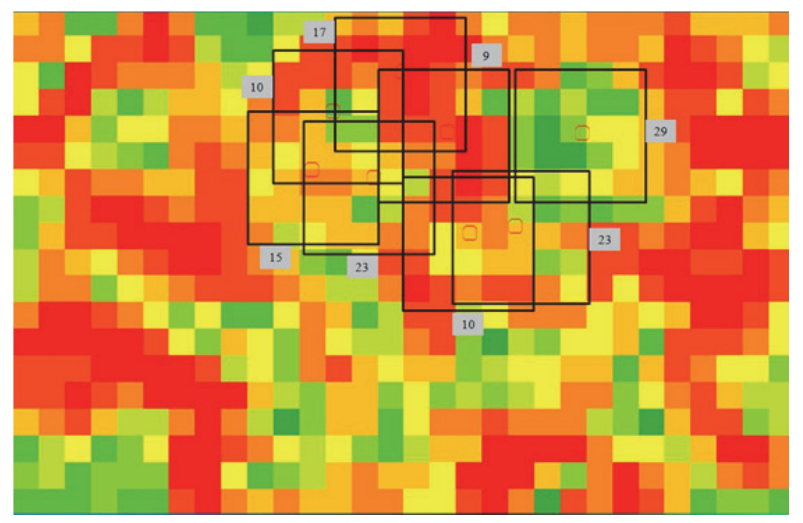

Figure 12. Proximity to sinkholes calculated for each cell

\subsection{Land-use potential hazard area}

The bare land mass has a low angle of repose as compared to grassy land or forest land which makes it more vulnerable to subsidence. After reclassification of the land-use map, approximately $11.8 \%$ of cells were critical for subsidence occurrence. The total number of cells was 67 (Table 5).

${ }^{12}$ The Filter tool in ArcGIS is used to eliminate spurious data or enhance features otherwise not visibly apparent in the data. Filters create output values by a moving, overlapping 5 x $5 \mathrm{~s}$ cell neighborhood window that scans through the input raster. As the filter passes over each input cell, the value of that cell and its 8 immediate neighbours are used to calculate the output value. 


\subsection{Land-subsidence risk}

After running the model in the ArcGIS environment in the model builder ${ }^{13}$, land-subsidence risk cells was calculated (Figure 13). The total potential hazard cells were 29 in the case study area. If we only considered the cells in the actual cave area, 11 cells were critical for land subsidence according to the geospatial subsidence hazard model.

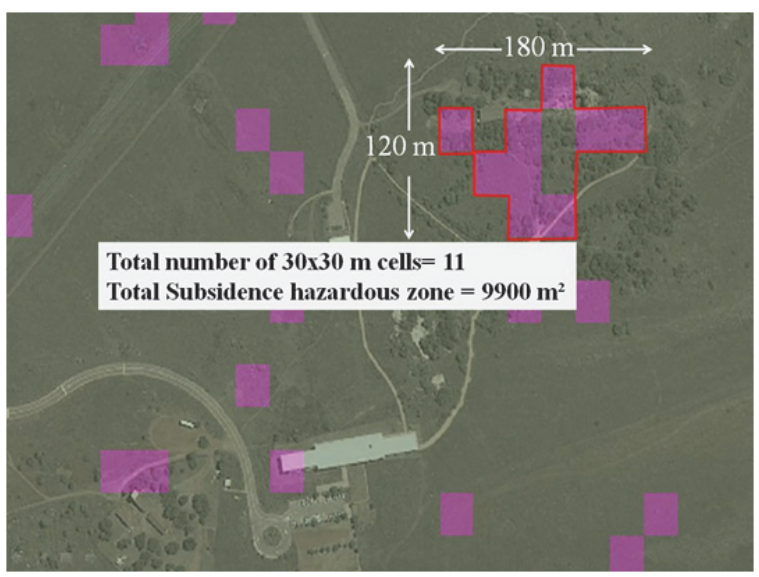

Figure 13. Potential hazardous zone in Sterkfontein cave area

\section{Conclusion}

Land subsidence is a serious geological hazard in terrains hosting caves. It is formed by a sudden collapse of the overlying soil. A method to assess the Sterkfontein caves area land subsidence potential was proposed based on GIS and AHP techniques.GIS and remote sensing technologies were used to build a geospatial subsidence hazard model for calculating the hazard areas, information extraction, and database development. Microsoft Access and GIS software were used to develop the database and database application tools for data input. These technologies helped create a hazard map based on varying factors which could be used to monitor the area for possible subsidence and detailed researches.

A GIS, geospatial reclassification tool was used to reclassify the factor maps for further analysis. GIS table functions were used to analyse the data statistically. The multi-criteria decision analysis technique was applied to the factor maps to weight different factors. A pairwise comparison matrix in AHP was developed and used in model to find out the subsidence hazardous areas.

The final quantitative land subsidence (probability) allowed the research group to analyse and assess the area for any future potential damage. The conclusion and recommendations that could be drawn from the study are as follows:

- The potential hazardous area marked on SPOT 5 imagery (Figure 13) should be further investigated. The condition of the cave roof must be carefully analysed by ground monitoring for any deformations or rock movement.

- This study included factors whose digital data was easily available. It is recommended that another detailed study incorporating additional geotechnical factors be carried out to increase the accuracy of the results.

- The GIS model built in the Sterkfontein cave area, can be applied to other sensitive areas for ground subsidence.

\section{References}

Abidin HZ, Djaja R, Darmawan D, Hadi S, Akbar A, Rajiyowiryono H, Sudibyo Y, Meilano I, Kasuma MA, Kahar J, Subarya C (2001) Land subsidence of Jakarta (Indonesia) and its geodetic monitoring system.Nat Hazards 23(23):365-387.

Aceves-Quesada JF, D1'az-Salgado, J, Lo'pez-Blanco J (2007) Vulnerability assessment in a volcanic risk evaluation in Central Mexico through a multi-criteria-GIS approach. Nat Hazards 40:339-356.

A. Klimchouk, "Morphogenesis of Hypogenic Caves," Geomorphology, Vol. 106, No. 1-2, 2009, pp. 100- 117.

\footnotetext{
${ }^{13}$ ArcGIS application is used to create, edit and manage models.
} 
A. Rawashdeh, R. Ruzouq, A. Al-Fugara, B. Pradhan, S. H. Abu-HamattehZiad and A. R. Ghayda, "Monitoring of Dead Sea Water Surface Variation Using Multi-Temporal Satellite Data and GIS,"Araabien Journal of Geosciences, 2012, p. 8

Chen K, Blong R (2003) Towards an integrated approach to natural hazards risk assessment using GIS: with reference to bushfires. Environ Manage 31:546-560.

Gambolati G, Teatini P (2002) GIS simulations of the inundation risk in the coastal lowlands of the Northern Adriatic Sea. Math Comput Model 35:963-972.

Hobbs P.J. (2011). Situation assessment of the surface water and ground water resource environment in the Cradle of Humankind World Heritage site. Establishment of a monitoring system for surface water and ground water in the Cradle of Humankind World Heritage site. Johannesburg: Department of Economic Development, Gauteng Provincial Government, pp. 1-152.

J. A. Green, W. J. Marken, E. C. Alexander Jr. and S. C. Alexander, "Karst Unit Mapping Using Geographic information system technology, Mower County, Minnesota, USA," Environmental Geology, Vol.42, No. 5, 2002, pp. 457-461.

J. Pacheco, J, Arzate, E. Rojas, M. Arroyo, V. Yutsis and G. Ochoa, “ Delimination of Ground Failure Zone due to Land Subsidence Using Gravity Data and Finite Element Modelling in the Queretaro Valley, Mexico," Engineering Geology, Vol. 84, No. 3-4, 2006, pp. 143-160.

Martini, J., Wilinger, P.E., Moen, H.F.G. \& Keyser, A. 2003. Contribution to theSpeleology of Sterkfontein cave, Gauteng province, South Africa. International Journal of Speleology 32: 43-49.

Pulis, S. (2011). Bayesian Underwriting of Sinkhole Exposure Revisited. Casualty Actuarial Society, E-Forum, pp. 111.

R. Brinkmann, M. Parise and D. Dye, "Sinkhole Distribution in a Rapidly Developing Urban Environment: Hillsborough County, Tampa Bay Area, Florida,” Engineering Geology, Vol. 99, No. 3-4, 2008, pp. 169-184.

Sinkholes and subsidence in South Africa. (2011). 2011-0010. Cape Town: Council for Geoscience, pp. 1-34.

S. Pirasteh, B. Pradhan and S. M. Rizvi, "Tectonic Process Analysis in Zagros Mountain with the Aid of Drainage Networks and Topography Maps Dated 1950-2001 in GIS," Arabian Journal of Geosciences, Vol. 38, No. 4, 2011 , pp. 171-180.

Scott, D., Versfeld, D. And Lesch, W. (1998). Erosion and sediment yield in relation to afforestation and fire in the mountains of the Western Cape Province, South Africa. South African Geographical Journal, 80(1), pp. 52-59.

The South African Karst Working group, (2010). The state of Karst ecology research in the Cradle of Humankind World Heritage site. The Karst system of the Cradle of Humankind World Heritage site. Johannesburg: Water research commission.

US Forest Service, (2009). Angle of Repose: Testing Erosion and Prescribed Fire in Eastern Oregon and Washington 's Blue Mountains. Fire science brief, issue 44. Washington DC: U.S. Joint Fire Science Program, University of Nebraska - Lincoln, pp. 31-37.

Y. Gao and E. C. Alexander, "Application of GIS Technology to Study Karst Features of SoutheasternMinnesota," In: Beck \& Herring, Eds., Geotechnical and Environmental Application of Karst Geology and Hydrology, Swets \& Zeitlinger, Lisse, 2001.

Y. Gao and E. C. Alexander, "Sinkhole Hazard Assessment in Minnesota Using a Decision TreeModel," Envi- Ron Geol Springer-Verlag Environmental Geology, 2008.

Y. Gao, "Karst Feature Distribution in Southeastern Minnesota: Extending GIS-Based Database for Spatial Analysis and Resource Management," Ph.D. Thesis, University of Minnesota, 2002. 